\title{
RABIH ALAMEDDINE, KIM ADDONIZIO, AND KELLIE WELLS: FAIRY-TALES IN THE $21^{\text {ST }}$ CENTURY
}

\author{
ELENA ORTELLS \\ Universitat Jaume I, Castelló
}

\begin{abstract}
The main aim of this study is to explore if and, if so, how Rabih Alameddine, Kim Addonizio, and Kellie Wells have managed to sustain, replicate, disregard, or redefine the patriarchal ideology customarily associated to gender issues within the fairy-tale tradition. What is really striking is that, several decades after the revisionist project undertaken by the "Angela Carter generation", these new voices experimenting with the field of fairy tales still feel the need to revisit the same mythemes and fight against the same ideology and values that pervaded twentiethcentury retellings of fairy tales. The subversive potential of the fairy tale retellings seems to have been surpassed by the powerful agenda of a patriarchal social system, which, despite the social, psychological, and political changes, still retains its status quo.
\end{abstract}

KEY WORDS: revisions, fairy tales, feminism, patriarchy.

Rabih Alameddine, Kim Addonizio y Kellie Wells: cuentos de hadas en el siglo XXI

El objetivo principal de este estudio consiste en explorar si y, de ser así, cómo Rabih Alameddine, Kim Addonizio y Kellie Wells han conseguido mantener, reproducir, olvidar o redefinir la ideología patriarcal normalmente asociada a las cuestiones de género dentro de la tradición de los cuentos de hadas. Lo que resulta sorprendente es que, varias décadas después del proyecto revisionista acometido por la "generación de Angela Carter", estas nuevas voces que experimentan en este ámbito sientan aún la necesidad de revisitar los mismos mitos y luchar contra la misma ideología y valores que impregnaron las reescrituras de los cuentos de hadas durante el siglo xx. El potencial carácter subversivo de las reescrituras de los cuentos de hadas parece haber sido superado por la poderosa agenda de un sistema social patriarcal que, a pesar de los cambios políticos y psicológicos, aún mantiene su posición dominante.

PALABRAS ClAVE: revisiones, cuentos de hadas, feminismo, patriarcado.

Fairy tales have been essentially conceived as reflective comments on the human condition and are deeply influenced by social, cultural, and historical circumstances. Contemporary critics have theorized about the potential of fairy tales to ponder upon our present and reflect upon the transformative powers of this genre (Bacchilega, 2015, 2013; Tatar, 2015; Zipes, 2011, 2012, 2015). Jack Zipes contends that "[f]airy tales are informed by a human disposition to action - to transform the world and make it more adaptable to human needs" (2012: 2). As Maria Tatar affirms, "they oblige us to react, to take positions, and make judgments, enabling us to work through cultural contradictions" (2015: 3). For 
Jack Zipes, the pervading presence of fairy tales in practically all art forms nowadays responds to our "persistent refusal to accept life as it is and [to] a demand that utopian longings be fulfilled" (2015: 194). For Vanessa Joosen, the fairy tale has remained relevant today because of its capacity "to provide readers [...] not only with nice stories but also with reflections on literature and on life" (2011: 303). In her Fairy Tales Transformed, Christina Bacchilega explores the modes and uses of the adaptations of fairy tales in the twenty-first century and delves into the logics behind the resurgence of the genre (2013: ix). Transformation seems to be for Bacchilega crucial to contemporary fairy tales (2013: 3).

The renewed interest in fairy tales and in their didactic and psychological potential can be originally found in the 1970's with the influential work of feminist scholars such as Alison Lurie and Marcia E. Lieberman. As Donald Haase reminded us in his canonical article "Feminist Fairy Tale Scholarship", "early feminist criticism of fairy tales, as seen in the Lurie-Lieberman debate, was principally concerned with the genre's representation of females and the effects of these representations on the gender identity and behavior of children" (2000: 16). In her article "Fairy Tale Liberation", Alison Lurie claimed that fairy tales could contribute to the emancipation of women because they portrayed strong female characters and, consequently, the genre should become "one of the few sorts of classic children's literature of which a radical feminist would approve" (1970: 42). Two years later, in 1972, Lieberman published a potent refutation of Lurie's assertions in "'Some Day My Prince Will Come': Female Acculturation through the Fairy Tale". This seminal study condemned the use of classical fairy tales to circulate the poisonous patriarchal myths employed to delude women. Its author argues that fairy tales have been made "the repositories of the dreams, hopes, and fantasies of generations of girls" and that "millions of women must surely have formed their psycho-sexual self-concepts, and their ideas of what they could or could not accomplish, what sort of behavior would be rewarded, and of the nature of the reward itself, in part from their favorite fairy tales" (1972: 385).

During the first decade of the twenty-first century, Rabih Alameddine, Kim Addonizio, and Kellie Wells, among many other writers, embarked on a project, commissioned by Kate Bernheimer, to offer "new" versions of the classical fairy tales. The result of this venture was the collection My Mother She Killed Me, My Father He Ate Me (2010). In order to understand the significance of these revisions, it is necessary to reflect upon the socio-historical context in which the classic fairy tales first came into being. In accordance with the social and ideological assumptions of the period, most of these literary pieces tended to reinforce patriarchal and patronizing notions of gender and authority. In some respects, the traditional fairy tales were primarily intended to assign proper roles for men and women in society. Consequently, this corpus became the ideal 
battleground for questions and constructions of sexuality, gender, and power. During the late twentieth century authors such as Anne Sexton, Angela Carter, Emma Donoghue or Margaret Atwood - christened by Stephen Benson as the "Angela Carter generation" (2008: 2) - initiated a prolific tradition of feminist rewriting of fairy tales. These writers mainly tried to recover the original but expurgated elements of most of these tales after they suffered a process of literary domestication at the hands of Charles Perrault, Madame de Beaumont, and the Grimm Brothers, among others. The "Angela Carter generation" entered into a dialogue with these versions, clearly imbued with he patriarchal bourgeois ideologies of their socio-historical contexts, challenging their principles, questioning their narratives, and reformulating their conclusions to, finally, regain the progressive allusions to sexuality and female authority of the original folktales. ${ }^{1}$ According to Daniela Carpi, this revisionist approach unsettled the readers' expectations and induced them "to abandon their complacent attitude towards a hypocritical, repressive and classist status quo" (2016: 12). With their rewritings, these authors censored reactionary attitudes and corrected customary biases regarding male and female behaviors as well as stereotypical notions of good and evil. Most of these narratives contained an emancipatory advice for their heroines, who usually chose not to conform to orthodox gender patterns and middle-class cultural values, in a clear attempt to vindicate the main tenets of the original sources.

At the dawn of this new century, Alameddine, Addonizio, and Wells seem to deal in their revisions of traditional fairy tales with motifs and themes similar to the ones used by their twentieth-century counterparts. In spite of having had their works published between 2006 and 2010, these three members of the "post-'Angela Carter generation"' (Bacchilega, 2015: 81), nevertheless, seemed to endorse similar gender and sexual politics and circulate literary manifestations akin to the ones exhibited by their predecessors. Hence, it is my intention to explore if and, if so, how the archetypal motifs, the stereotypical characters, and the ideological overtones of the traditional fairy tales and their twentieth-century retellings have been appropriated and altered by these twenty-first century writers. My aim is to study if and, if so, how these authors have adapted their retellings to contemporary social changes and whether the literary pieces resulting from this intertextual dialogue respond to the ideological concerns of our world and demonstrate their relevance for our time.

\footnotetext{
1 "When she [Angela Carter] was asked in 1985 if her intention had been to subvert and feminise a patriarchal form, she said: 'Not really. I was taking [...] the latent content of those traditional stories and using that; and the latent content is violently sexual. And because I am a woman, I read it that way" (Gordon, 2017: 268).
} 
Rabih Alameddine's “A Kiss to Wake the Sleeper” (2010), Kim Addonizio's "Ever After" (2010), and Kellie Wells's “The Girl, The Wolfe and the Crone” (2010) will serve these purposes. This selection has been determined by the socio-cultural significance and historical relevance of their archetypal protagonists and by their capacity to use the original memes to subvert oppressive structures and to radically disrupt the horizon of expectations of traditional fairy tales (Joosen, 2011: 13). The protagonists of these narratives belong to the most popular traditional fairy tales in the Western world and, consequently, are among the ones most frequently retold and analyzed. Sleeping Beauty, Snow White and Little Red Riding Hood resonate in our minds as openly illustrative of the poisonous patriarchal myths used to deceive women. Moreover, the three revisions share two common traits that make them suitable for comparative purposes. Firstly, Judeo-Christian iconography pervades all three texts, underlying how God and religion have always functioned as legitimizing factors for the institution of patriarchy. ${ }^{2}$ As Bottigheimer states, "fairy and folk tales have served the church for centuries as an integral part of sermons and as a secular means of instruction" (1986: 6). In addition to this, criticism of the psychoanalitic uses of the fairy tale is raised by the three texts through the parodic use of sexual symbology (Tatar, 1992; Zipes, 1988).

The present analysis is mainly rooted in feminist fairy-tale criticism and gender studies (Bacchilega, 1997; Gilbert and Gubar, 1979; Haase, 2000; Joosen, 2011; Tatar, 1992, 2015; Zipes, 1986) and complemented with some ideas drawn from psychoanalysis (Mulvey, 1975; Schanoes, 2014) and structuralist criticism (Genette, 1997). Ethologist Richard Dawkins's notion of meme as adapted to the literary field by Jack Zipes in his Relentless Progress will be used as a starting point. According to this scholar and literary critic, a meme is "a cultural artifact that acts as a cultural replicator or cultural adaptator and manages to inhabit our brains and to become so memorable and relevant that we store it and pass it on to other humans" (2009: 88). Following Genette's approach and terminology, we will see that the traditional memes of Sleeping Beauty, Snow White, and Little Red Riding Hood are pragmatically transposed in my choice of twenty-first century revisions in an attempt to thematically transform their hypotexts ${ }^{3}$ and to modify their socio-

\footnotetext{
${ }^{2}$ Although, for some time, the term patriarchy had fallen into disuse since many critics considered it as "too blunt and monolithic to capture the nuances of oppression", it experimented a revival in the light of the \#MeToo campaign (October 2017) as it came to be regarded by many as "the word to explain the continued existence of pervasive inequality" (Higgins, 2018). Its resurgence in the twenty-first century has been accompanied by a new wave of feminism, a fourth wave of feminism. The return of these two concepts - patriarchy and feminism - to the public debate is clearly explained by the fact that gender inequality has not been eradicated yet.

${ }^{3}$ Genette uses the term "hypertextuality" to refer to "any relationship uniting a text B [...] to an earlier text A [...], upon which it is grafted in a manner that is not of commentary" (1997: 5). The
}

262

Lectora, 27 (2021): 259-273. ISSN: 1136-5781 D.O.I.: 10.1344/Lectora2021.27.13 
cultural and psychological resonances. Through "transdiegetizations" (Genette, 1997: 296), ${ }^{4}$ original transpositions of point of view or profound resistance to orthodox gender role assignments and conventional denouements, the twentyfirst century authors object of our study endeavor to invest the traditional fairy tales with "new" complexity and depth and entirely "different" significances. Close analysis of the texts proposed will lead us to reflect upon fairy tales as primary sites for deconstructing long-established models of gender and subverting deep-rooted patriarchal ideologies. However, are these "activist adaptations"5 (Bacchilega, 2015: 80) different from their twentieth-century counterparts? This article has been conceived as an attempt to respond to this question.

Resorting to the unconventional point of view of an unnamed young woman suffering from a rare illness, Rabih Alameddine presents, in "A Kiss to Wake the Sleeper" (2010), an atypical transdiegetization of "Sleeping Beauty". Although the connection between hypotext and hypertext is made explicit from the very beginning through a paratextual allusion (the title), the diegetic transposition that leads from the former to the latter is carried out through a distinctive and multifaceted transformation. By initially foregrounding the special circumstances in the life of the narrator and by altering the chronotope of the traditional fairy tale, the author mischievously deviates the reader's attention from the original meme and underlines the originality of the new framework. After thirteen years of living inside a sterile bubble, our storyteller abandons her place of seclusion and engages in a strenuous journey in search of a cure. ${ }^{6}$

However, soon, the unambiguous description of the setting and circumstances together with the reference to the instantly recognizable protagonist serve the narrator to trigger the hypotextual analogy and evoke the classic tale: "In a small room in the tower the beauty slept and breathed, while everything in the palace, everyone else breathed no more" (414). Moreover, in this retelling of the story, Alameddine seems to take cue from the revisionist tradition of fairy tales that

transformations experimented by the hypotexts (Text A) result in the hypertexts (Text B), which are the object of my study.

${ }^{4}$ Transdiegetization or diegetic transposition is to be understood here as a change in "the spatiotemporal world designated by the narrative" (Genette, 1997: 295). This transformation obviously affects the action and, consequently, alters the reader's perception of the events.

${ }^{5}$ Bacchilega refers to these revisions as "activist adaptations", as "retellings in different media that take a questioning stance towards their pre-texts, and/or take an activist stance towards the fairy tale's hegemonic uses in popular culture, and/or instigate readers/viewers/listeners to engage with the genre as well as with the world with a transformed sense of possibility" (2015: 80).

${ }^{6}$ The reader gets only the limited perspective of this young female narrator, who is positioned as an unreliable narrator because of her illness. 
satirizes psychoanalytic views of literature by making use of the same simplistic symbolic translations of sexual references that are exhibited by their canonical predecessors. The phallic symbol of the sword fighting its way through the premises evokes the strong sexual associations that psychoanalysis attributes to fairy tales. Hence, a multitude of princes jump off their horses, unsheathe their swords, and try to clear their path through the thorns (418). The parody continues in the following lines when, after leaving behind a multitude of princes swallowed dead by the brier or killed by "murderous plants" or "poisonous snakes" (419), the hero comes through, enters the room, and stops in front of Sleeping Beauty.

Nevertheless, the horizon of expectations of the reader is totally disrupted when the prince is presented as a froggish Christ-like figure. While "streaked in blood", with "deep wounds on his forehead, on his side, on both palms", he "extended his tongue and licked the moistness of her cleavage" (420), before kissing her. The deep wounds mentioned in this quote clearly evoke Christ's injuries while being crucified and act as a reminder of the connection between the Judeo-Christian tradition and patriarchy. The role of this tradition in bolstering patriarchal values in society is all too obvious. Ever since Eve's consumption of the forbidden fruit and mankind's expulsion from the Garden of Eden, women have been painted by religion as physically, mentally, emotionally and sexually inferior to men. By being presented as a Christ-like figure, the prince becomes the impersonator of the tenets of such a patriarchal system and ignites the confrontation with the female character. However, on presenting him also as a "froggish" figure, Alameddine ridicules the prince, questions his significance and bolsters a parody of psychoanalytic interpretations of fairy tales.

Then, this embodiment of Judeo-Christian iconography resorts to violent sexual intercourse to awaken the sleeping princess: "He tore off the blouse and chemise, squeezed her milk-white breasts, pinched them, bit them with abandon [...]. And he tore off her skirt and undergarments" (421). It is then when, far from reproducing the archetypal behavior of Sleeping Beauty, that of the damsel in distress, the passive victim, the apparently lifeless heroine awakens screaming in ecstasy and actively engages in the passionate exchange. Alameddine's rewriting of the classic rape-scene radically undermines Sleeping Beauty's typical valueladen traits and challenges Kolbenschlag's description of the standard character: "Sleeping Beauty is most of all a symbol of passivity, and by extension a metaphor for the spiritual condition of women - cut off from autonomy and transcendence, from self-actualization and ethical capacity in a male-dominated milieu" (qtd. in Barzilai, 2015: 61). In a dramatic reversal of the psychoanalytic interpretations of gender roles in fairy tales (Bettelheim, 1976; Schanoes, 2014), although at first "entering the princess brutally", the prince becomes no longer the conqueror, the princess adopts an active role and is portrayed as tearing "off his pantaloons" and 
"push[ing] herself into him in return", and the couple are ultimately rendered as "attack[ing] each other in an aggressive ancestral rhythm" (421). Similarly to what happened in most of the retellings of the "Angela Carter's generation", gender equality and savage female sexuality pervade this narrative. We assist to "[a] return to an older convention of the fairy tale", what can be called a "re-sexualization" or "introduction of sexual references" (Joosen, 2011: 168). Extremely subversive in the erotic nature of the princess's awakening, Alameddine's adaptation disregards then the heteronormative figure of the Christ-like prince as savior and renegotiates the gender power relations encoded into the archetypal narratives. Likewise, since "the marriage ending is the illusion of a mutually satisfying relation between men and women in patriarchy" (Seifert, 2004: 67), by departing from this stereotypical closure, he circulates an ideological vision that clearly opposes gender-established roles and overtly parodies the "happily ever after" formula.

Moreover, by resorting to a young female perspective to shape the story, Alameddine undermines the typical narratological pattern of the traditional tale and questions the objective, authoritative and patriarchal voice of its omniscient narrator in order to present other sides of the story. A female gaze substitutes here the male gaze (Mulvey, 1975), the traditional tale's third-person narrative. Relying on Lacan's formulations regarding desire, it can be argued that the author of "A Kiss to Wake the Sleeper" uses the female gaze of the teller to deconstruct the model of gender offered by male voices and to introduce innovative nuances regarding the sexual encounter at the core of the narrative: "Desire is not the private affair it appears to be but is always constituted in a dialectical relationship with the perceived desires of other subjects" (Evans, 1996: 39). The contemplation of the violent sexual intercourse functions as a definitive mechanism which contributes to the healing process of the observer, who leaves the room "bloodied and bleeding" but also "refreshed and rejuvenated" (422). It is not accidental, thus, that the figure of a "healthy and joyful" (422) female narrator emerges triumphantly against a background of "corpses of failed princes" (422) since the experience has helped her to leave behind her frailties, to bolster her assertiveness and to strengthen her identity as a woman.

The concluding lines of the story serve then to conceive the narrative as a reflection of a young woman's spiritual development and maturation, upholding a parodic version of the traditional fairy tale heroine's initiation. The ending of Alameddine's revision radically departs from the conventions of established fairy tales and serves well to feminist interpretations of the text. Hence, the heroine is not reintegrated into the patriarchal space of the castle or palace. The typical scene of many of the fairy tale closures in which the protagonist reunites with her fiancé, husband, or father in this "male dominion", is substituted here with a return to a matriarchal figure. Not only that, Alameddine characterizes the female storyteller 
as a Christ-like figure who ends the narrative acknowledging her return to Mother, wearing "a tiara of thorns" (422). Through the attribution of Judeo-Christian imagery to a female character, to some extent at least, the writer manages to destabilize preconceived notions regarding the overtly acknowledged connection between religion and patriarchy and to endorse new constructions of sexuality, gender, and power.

With this conclusion, Alameddine pays his particular homage to women's traditional roles as storytellers (Rowe, 1986) and to the matriarchal values that remained hidden in a literary form that, along history, aligned very quickly with the tenets and insights of patriarchy: "In this view the fairy tale becomes a coded text in which the female voice, despite the attempt by men to control it, not only continues to speak but also speaks a secret, subversive language" (Haase, 2000: 29). Thus, this version of Sleeping Beauty makes a compelling case for the contemporary reversal of the process undertaken by fairy tales in the past when editorial emmendations suppressed female power and reenacted themes comprising gender and sexuality (Haase, 2000: 28). However, in relation to its immediate twentiethcentury predecessors, one cannot help but observe a substantial limitation: its lack of originality since Alameddine does nothing but reproduce formulae similar to the ones employed by his forerunners.

Kim Addonizio's "Ever After" (2010) constitutes the illustration of the author's reflections on community formation and rupture. In this short story, Addonizio explores the beliefs around which we structure our lives and give them meaning, drafting a controversial connection between religion and fairy tales, and sacralising the latter ones. The author affirms, "I don't see any difference between worshipping Snow White or the Virgin Mary or Allah, since they are all fantasies" (Bernheimer, 2010: 526). Whereas the reference to the stepmother and her mirror or the inclusion of citations such as "[s] he ate the apple, she fell" (519) serve as a clear sign of diegetic faithfulness to the classic source, the change in the social and historical setting clearly evinces the transdiegetization from the hypotext. This revision relocates the story to a twenty-first century venue. Addonizio's seven sordid dwarves live in a loft with a view of the city, and they have been waiting "for more than six years already" (514) for the "happily ever after" promised in the Book and embodied in the figure of Snow White, the emblem of domesticity in the traditional story, who is missing here. The perfect virginal figure, who will become a servant in the dwarves' household, is absent from this narrative. In a clear attempt to challenge the idealized portrait of the classic Snow White, the author of this version chooses to dispose of the patriarchal archetype of "the angel in the house".

Although never explicitly mentioned and always referred to as "the Book", Snow White and the Seven Dwarfs is equated to the Bible and it is the element that shows Doc that "there was a purpose to his life" (514), this purpose being "to 
gather the others, to come to this place and make it ready" (514). After finding the Book in a Dumpster, he quits drinking, finds a job and gathers his brethren, giving the community of dwarves hope: "She and the dwarves, Doc thought, all of them together. She would come, and see that he had made things ready" (519). And, not only that but, as a Christian-like savior, "she would take the pain that had always been with him, the great ache of loneliness at the center of his life, into her hands, like a trembling bird" (519). Thus, through Doc's gaze, Addonizio attributes Snow White new capacities. The female figure departs from her original archetype and becomes the embodiment of the central figure of the Judeo-Christian tradition. Hence, the mythemes of the story are given sanctity through pragmatic transposition.

However, in a curious reversal of gender roles, a common scheme in fairy-tale retellings, Doc ends up thinking of himself as the object of desire - "he was the one she came for, the only one" (516) - and forgets about his dream of a domestic community with the rest of his companions: "they [Snow White and himself] could leave all the others behind. They would leave the city and move to an Airstream in the woods, overlooking a little river, where he could catch bass and bluegills. She would stand in front of their stove in cutoffs and a white blouse, sliding a spatula under a fish sputtering in a pan" (516). Nevertheless, one of his brethren, Grumpy, will soon awaken him from his dream. He will be the one to unveil Doc's delusion and the futility of his reverie: "my name isn't Grumpy [...]. It's Carlos. I'm a Puerto Rican [...]. I'm sick of all of you with your fake names and voodoo loser fantasies about some chick who ain't coming. She ain't coming, man" (520).

Snow White, who, in this text, goes unnamed and is initially presented as "the goddess who would come with the sacred apple and transform them" (512-3) is not coming "[a]nd she would never come, not to a lone dwarf" (521). Despite her physical absence, Snow White pervades the narrative impersonating the figure of a reborn female Christ: "she will die of the apple and be resurrected" (515). However, Snow White's most improbable resurrection transforms the story of salvation into one of self-delusion since, without her, there is no hope for the dwarves. Therefore, contrarily to "the words that had given him such faith the first time he read them: They lived happily ever after" (519), there is no happy end for Doc: "There was no black-haired goddess, eyes dark and full of love, floating toward him. He polished the apple on his shirt [...]. [H] e could see that out there, in the big world, there was nothing anymore to wish for" (525). These final thoughts serve as a powerful antidote to the formula of "happily ever after", destabilizing a conventional reading of the text and circulating a formally parodic interpretation.

In fact, by leaving out of the narrative or subverting some of the several issues that have traditionally articulated retellings of the classic fairy tale, Addonizio decides against the institutionalized text and undermines its patriarchal 
foundations. Hence, the nonappearance of Snow White allows the author not only to obviate "the battle between two mythic images with which patriarchy has tried to grasp women: the angel and the witch"7 (Joosen, 2011: 216) but, most importantly, to save the heroine from having to submit to the predestined roles of domestic servant and wife. Similarly, an analogous course can be seen in averting the voice of the mirror, "a distinctly patriarchal instrument" (219). Thus, by excluding the looking glass, Addonizio undermines and silences the authoritative voice of the male-controlled system. Likewise, the writer also opts for denying the masculine figures of the traditional narrative - the prince and the dwarves - their role as Snow White's saviors. Far from being a key figure for the final denouement, the prince becomes a non-presence and the dwarves have no role left to play in a drama that no longer takes place. Thus, striking as it may be that these textual elements disappear in the retelling, their absence unveils a clear attempt on the author's side to incorporate a social critique against the patriarchal constraints of the genre and to disrupt their established directives. Nevertheless, however curious this proposal may appear, it departs little from its twentieth-century equivalents.

Referring to "The Girl, the Wolf, the Crone" (2010) as "a shared hallucination" between writer and reader, Kellie Wells goes beyond the mere attempt at creating a metafictional exposé of the archetype (Bernheimer, 2010: 360). By altering the conventional role assignment and the predictable ending of Little Red Riding Hood, this revision ostensibly disrupts the horizon of expectations of its readership, criticizes oppressive structures of patriarchal supremacy, and circulates a narrative of female agency and woman liberation. In fact, Wells's account creates a rupture with the canonical tradition of Little Red Riding Hood. More than with the well-known versions of Charles Perrault and the Brothers Grimm, "The Girl, the Wolf, the Crone" enters into a dialogue with "The Story of Grandmother", an oral tale from the seventeenth century, recorded in Brittany in 1885. In this narrative, the little girl arrives at grandmother's house, eats meat, and drinks wine that turn out to be her grandmother's flesh and blood, gets into bed with the wolf and finally escapes.

Wells's revision lays bare from the very beginning the parodic purpose of its author. Rather than with the traditional "once upon a time" formula of classic fairy tales, Wells chooses to open this adaptation with the expression "[m]ore than once", a clear indicator that she is going to revise the hypotext both formally and thematically. Hence, distancing itself from the cautionary and didactic nature of the Perrault's and the Grimms's versions, "The Girl, the Wolf and the Crone" visibly evinces a semantic transposition of the hypotext through an unforeseen

\footnotetext{
${ }^{7}$ The female archetypes of the angel and the witch are deeply rooted in Christian imagery (Joosen, 2011: 287).
} 
reversal of gender roles. In a surprising turn, the feral protagonist becomes the "sickly wolf who would like nothing better than to receive stale bread from a girl like her" (353), and his place in the perilous woods is taken over by crones, those "primordial women with faces like the bottom of a river" (353). Thus, the frightening male predators of the forests are converted into these "crusty old wom[e]n with [faces] like fallen cake[s]" (353). Moreover, it is the crone of the title who takes over the role of the grandmother and, in a paradoxical reversal of the Little Red Riding Hood tradition, once she arrives at the house, impersonates and personifies the wolf, a wolf "who looked half-dead already, more moth-eaten pelt than glamorous savage, not even fit to be a stole" (354). This unexpected twist suggests a manifest parody of fairy-tale conventions.

Through a radical pragmatic transformation, the wolf and the crone/grandmother challenge the original assumptions traditionally attributed to these familiar characters. In a theatrical ceremony that reminds us of the Catholic Eucharist, the wolf becomes a Christ-like figure who, from inside the crone's belly, recites "[t]ake, eat, [...] this is my body, which is broken for you" (354). Similarly, later on, the huntsman will be the recipient of the wine and will hear "a gauzy voice as if from under a hidden pillow" (358) reminding him of Matthew 26: 27, 28 : "Drink ye all of it, for this is my blood". Evoking the religious metaphor of the Judeo-Christian tradition, bread and wine in this retelling stand for the body and blood of the feral creature and not the grandmother's. However, coming from the most profound of the crone's body, the patriarchal voice is visibly undermined. Thus, after taking the wolf s body "dutifully into her mouth" (354), the old woman undresses, steps inside the wolf skin (previously unzipped by his owner) and prepares "to be the recipient of a steady supply of pity and bread" (355) from Little Miss Red Cheeks.

Wells takes the subversion of the fairy tale a step further and Little Miss Red Cheeks refuses to model her behaviour after the traditional character. Echoing Delarue's folklorist tale, the naïve protagonist of the Perrault and Grimm tales becomes here the cunning deceiver who "smiles at him [the wolf] pityingly, thinking some poor creatures are simply doomed by instinct" (355-356) and questions his role as a dangerous creature: "Oh, wolf! [...] How can you properly terrorize woodland creatures with only raggedy fur and a pudding of flesh with which to spook them?" (356). However, after crawling into bed with whom she considers the wolf, she is swallowed by the old woman, in a clear evocation of the figure of the witch or wicked stepmother of traditional fairy tales.

To the endless battle of sexes metaphorically portrayed in the established versions of the tale (Fromm, 1951: 241), Wells adds a story of intergenerational rivalry in which family ties are problematized. The author reconfigures the relationship between grandmother, mother, and daughter and transforms it into a 
parody of the Holy Trinity in which the loaf of bread becomes the object of desire. As happened in "The Story of a Grandmother" and in Perrault's version, the mother's sense of responsibility for the grandmother and the reciprocal love between grandmother and granddaughter are obviated in this account. Thus "The Girl, the Wolf and the Crone" enters into a dialogue not only with the multiple and varied versions of Little Red Riding Hood but also with differing notions of womanhood, motherhood, and mother-daughter relations.

By recovering the huntsman of the Brothers Grimm's Little Red Cap, Wells foregrounds the traditional figure of the male as savior and circulates ideological remnants of a patriarchal order. Moreover, the man sees in the girl an object of desire, and, as a gentle rescuer, he seems to raise obscene thoughts in Little Miss Red Cheeks. Consequently, this interaction can be initially catalogued as disruptive of heteronormative assumptions about male-female sexual relations. However, the man ultimately decides that "no brazen-faced rose that rutilant was worth deflowering" (359).

The parody of the hypotext extends itself well into the hypertext and its satirical function is rounded up at the end of the narrative when, in a clear evocation of another classic figure in fairy tales, that of Snow White's wicked stepmother, the old-old woman "looked at herself in the shiny dowager's hump of a soup spoon, and admired the salvaged eyesore she'd become" (359). Wells sets up to alter her readers' formulaic expectations and just as "the shiny dowager's hump of a soup spoon" (359) acts as a substitute for the iconic mirror, monstrosity and not beauty is alluded to as a desirable quality.

Therefore, it can be argued that Kellie Wells forged her narrative to question the rationale of patriarchal supremacy and to challenge the heteronormative roles and attributes traditionally reserved for women. By reversing gender roles and fostering women's agency, Wells emphasizes the fundamentals of female empowerment and subverts the traditional readings of fairy tales. By pushing the limits that restrain them, her multifaceted characters choose "not to conform to stereotypical gender patterns" (Joosen, 2011: 47). What is more, Wells adopts a critical stance towards psychoanalytical readings of fairy tales and "The Girl, the Wolf, the Crone" becomes the perfect example of how "the positive impact of psychoanalysis as a model for interpreting fairy tales seems to have passed and made way for a playful parody of its premises" (133). Nevertheless, despite offering solid grounds for all these insightful reflections, Wells's version does nothing but reiterate the dynamics of most of the revisions undertaken by Angela Carter's cohort.

Although limited in scope, this paper has explored how Alameddine, Addonizio, and Wells manage to sustain, replicate, disregard, or redefine the patriarchal ideology traditionally associated to gender issues within the fairy-tale textual genre. By deciding to place the traditional stories in contemporary settings, 
to alter point of view, to subvert gender roles, and to resolve against the traditional "happy ending", the twenty-first century fairy-tale retellings here analyzed encourage the revision of gender stereotypes and celebrate the emancipation of female characters. Thus, we may affirm that these twenty-first century fairy tales undermine patriarchal ideology and act as a corrective of traditional gender models and sexual stereotypes.

Nevertheless, how are these revisions different from their twentieth-century counterparts? In the light of the texts analyzed, it may be argued that the supposedly innovative revisions examined are reminiscent of the late twentiethcentury retellings and possess comparable cultural power. They feature the current penchant to subvert their classical versions in order to defy orthodox representations of gender roles and sexual behavior. As happened with their predecessors, these modern retellings cast off the model of the heroine held up as normative in fairy tales and show a reinvention of traditional women roles. The queens and princesses, mothers and stepmothers, witches and fairies of old fairy tales are placed in "new" contexts and conferred "new" attributions. As a result, their accomplishments seem to evoke "new" associations and, apparently, "new" stories are born.

However, what the retellings analyzed in this article evince is how, several decades after Sexton, Carter, Donoghue, and Atwood experimented with and deconstructed the fairy tale genre in order to subvert patriarchal structures of power, Alameddine, Addonizio, and Wells are still undertaking similar experiments and employing related deconstruction techniques to question clearly established hierarchies and ideologies. What is really striking is that, several decades after the revisionist project undertaken by the "Angela Carter generation", these three voices experimenting with the field of fairy tales still feel the need to revisit the same mythemes and fight against the same ideology and values that pervaded twentieth-century retellings of traditional fairy tales. The subversive potential of the fairy-tale retelling seems to have been surpassed by the powerful agenda of a patriarchal social system, which, despite the social, psychological, and political changes, still retains its status quo. Nevertheless, I would like to conclude on an optimistic note by underlying that the persistence of the fairy tale genre nowadays raises questions about the power of literature as a reflexive critical tool and demonstrates that these narratives still have a role to perform in the gender and social politics of today's world.

\section{WORKS CITED}

Addonizio, Kim (2010), "Ever After”, My Mother She Killed Me, My Father He Ate $\mathrm{Me}$, Kate Bernheimer (ed.), London, Penguin: 512-526. [2006] 
Alameddine, Rabih (2010), “A Kiss to Wake the Sleeper”, My Mother She Killed $\mathrm{Me}, \mathrm{My}$ Father He Ate Me, Kate Bernheimer (ed.), London, Penguin: 411-422. [2006]

Bacchilega, Christina (1997), Postmodern Fairy Tales. Gender and Narrative Strategies, Philadelphia, University of Pennsylvania Press.

-(2013), Fairy Tales Transformed? Twenty-first-century Adaptations and the Politics of Wonder, Detroit, Wayne State UP.

-(2015), "Fairy Tale Adaptations and Economies of Desire", The Cambridge Companion to Fairy Tales, Maria Tatar (ed.), Cambridge, Cambridge UP: 7996.

Barzilai, Shuli (2015), "While Beauty Sleeps: The Poetics of Male Violence in Perceforest and Almodovar's Talk to her", The Cambridge Companion to Fairy Tales, Maria Tatar (ed.), Cambridge, Cambridge UP: 60-78.

Benson, Stephen (ed.) (2008), Contemporary Fiction and the Fairy Tale, Detroit, Wayne State UP.

Bernheimer, Kate (ed.) (2010), My Mother She Killed Me, My Father He Ate Me, London, Penguin. [2006]

Bettelheim, Bruno (1976), The Uses of Enchantment. The Meaning and Importance of Fairy Tales, New York, Alfred Knopf.

Bottigheimer, Ruth B. (ed.) (1986), Fairy Tales and Society: Illusion, Allusion and Paradigm, Pennsylvania, University of Pennsyilvania Press.

Carpi, Daniela (2016), Fairy Tales in the Postmodern World, Heidelberg, Universitätsverlag Winter.

Evans, Dylan (1996), An Introductory Dictionary of Lacanian Psychoanalysis, London \& New York, Routledge.

Fromm, Erich (1951), The Forgotten Language: An Introduction to the Understanding of Dreams, Fairy Tales and Myths, New York, Rinehart.

Genette, Gerard (1997), Palimpsests. Literature in the Second Degree, Lincoln \& London, U. of Nebraska Press. [1992]

Gilbert, Sandra M. and Susan Gubar (1979), The Madwoman in the Attic: The Woman Writer and the Nineteenth-Century Literary Image, New Haven, Yale UP.

Gordon, Edmund, (2017), The Invention of Angela Carter: A Biography, Oxford, Oxford UP.

Haase, Donald (2000), "Feminist Fairy Tale Scholarship: A Critical Survey and Bibliography”, Marvels \& Tales: Journal of Fairy-Tale Studies, 14 (1): 15-63.

-(ed.) (2004), Fairy Tales and Feminism. New Approaches, Detroit, Wayne State UP.

272

Lectora, 27 (2021): 259-273. ISSN: 1136-5781 D.O.I.: 10.1344/Lectora2021.27.13 
Higgins, Charlotte (2018), "The Age of Patriarchy: How an Unfashionable Idea Became a Rallying Cry for Feminism Today", The Guardian, 22/6/2018. $<$ https://www.theguardian.com/news/2018/jun/22/the-age-of-patriarchyhow-an-unfashionable-idea-became-a-rallying-cry-for-feminism-today>

Joosen, Vanessa (2011), Critical and Creative Perspectives on Fairy Tales. An Intertextual Dialogue between Fairy-Tale Scholarship and Postmodern Retellings, Detroit, Wayne State University Press.

Lieberman, Marcia (1972), “'Some day my prince will come’: Female Acculturation through the Fairy Tale", College English, 34: 383-95.

Lurie, Alison (1970), "Fairy Tale Liberation", New York Review of Books, 17/12/1970: 42-44.

Mulvey, Laura (1975), "Visual Pleasure and Narrative Cinema”, Visual and Other Pleasures, New York, Palgrave Macmillan: 14-30.

Rowe, Karen E. (1986), “To Spin a Yarn: The Female Voice in Folklore and Fairy Tale", Fairy Tales and Society: Illusion, Allusion, and Paradigm, Ruth Bottigheimer (ed.), Pennsylvania, University of Pennsyilvania Press: 53-74.

Schanoes, Veronica L. (2014), Fairy Tales, Myth, and Psychoanalytic Theory, Farnham, Surrey, Ashgate.

Seifert, Lewis C. (2004), "Feminist Approaches to Seventeenth-Century Contes de Fees", Fairy Tales and Feminism. New Approaches, Donald Haase (ed.), Detroit, Wayne State UP: 53-71.

Tatar, Maria (1992), Off with their Heads! Fairy Tales and the Culture of Childhood, Princeton, Princeton UP.

-(2015), The Cambridge Companion to Fairy Tales, Cambridge, Cambridge UP. Wells, Kellie (2010), “The Girl, The Wolfe and the Crone”, My Mother She Killed Me, My Father He Ate Me, Kate Bernheimer (ed.), London, Penguin: 353-360. Zipes, Jack (1986), Don't Bet on the Prince: Contemporary Feminist Fairy Tales in North America and England, New York, Methuen.

-(1988), The Brothers Grimm: From Enchanted Forests to the Modern World, New York, Routledge.

-(2011), "The Meaning of Fairy Tale within the Evolution of Culture", Marvels \& Tales, 25 (2): 221-243.

-(2012), The Irresistible Fairy Tale. The Cultural and Social History of a Genre, Princeton, Princeton UP.

-(2015), Grimm Legacies. The Magic Spell of the Grimms' Folk and Fairy Tales, Princeton, Princeton UP. 